\title{
A tetravalent dengue nanoparticle stimulates antibody production in mice
}

\author{
Elisângela F Silva', Mariana Orsi', Ângela L Andrade², Rosana Z Domingues ${ }^{3}$, Breno M Silva ${ }^{4}$, \\ Helena RC de Araújo ${ }^{5}$, Paulo FP Pimenta ${ }^{5}$, Michael S Diamond ${ }^{6}$, Eliseu SO Rocha ${ }^{7}$, Erna G Kroon ${ }^{7}$, \\ Luiz CC Malaquias ${ }^{1}$ and Luiz FL Coelho ${ }^{1 *}$
}

\begin{abstract}
Background: Dengue is a major public health problem worldwide, especially in the tropical and subtropical regions of the world. Infection with a single Dengue virus (DENV) serotype causes a mild, self-limiting febrile illness called dengue fever. However, a subset of patients experiencing secondary infection with a different serotype progresses to the severe form of the disease, dengue hemorrhagic fever/dengue shock syndrome. Currently, there are no licensed vaccines or antiviral drugs to prevent or treat dengue infections. Biodegradable nanoparticles coated with proteins represent a promising method for in vivo delivery of vaccines.
\end{abstract}

Findings: Here, we used a murine model to evaluate the IgG production after administration of inactivated DENV corresponding to all four serotypes adsorbed to bovine serum albumin nanoparticles. This formulation induced a production of anti-DENV IgG antibodies ( $p<0.001$ ). However, plaque reduction neutralization assays with the four DENV serotypes revealed that these antibodies have no neutralizing activity in the dilutions tested.

Conclusions: Our results show that while the nanoparticle system induces humoral responses against DENV, further investigation with different DENV antigens will be required to improve immunogenicity, epitope specicity, and functional activity to make this platform a viable option for DENV vaccines.

Keywords: inactivated Dengue vírus, Nanoparticles, humoral response

\section{Background}

Dengue virus (DENV) is a major public health problem worldwide, especially in the tropical and subtropical areas with around 2.5 billion people living in areas at risk [1]. The disease is caused by a positive sense, single-stranded RNA virus that belongs to genus Flavivirus, family Flaviviridae. DENV is transmitted to humans primarily after a bite by an infected Aedes aegypti and Aedes albopictus mosquitoes. Infection with one of the DENV serotypes (DENV-1, -2, -3 and -4) causes a mild, self-limiting febrile illness called dengue fever (DF). However, after secondary infection, a small subset ( 0.5\%) develop the dengue hemorrhagic fever (DHF)/ dengue shock syndrome (DSS), the severe form of the disease [2].

\footnotetext{
*Correspondence: coelho@unifal-mg.edu.br

'Institute of Biomedical Science, Federal University of Alfenas, Minas Gerais, Brazil

Full list of author information is available at the end of the article
}

While vaccines could potentially prevent DENV infection or disease in humans, none are currently licensed despite decades of intensive research [3]. To date, several approaches have been developed towards generating a tetravalent anti-DENV vaccine including live-attenuated strains, inactivated strains, subunit DNA or plasmid vaccines, and recombinant proteins [4]. Our group has begun vaccine studies using a unique platform, the nanoparticles. Biodegradable nanoparticles are currently used as drug carriers or as adjuvants for vaccines [5]. Polymeric nanoparticles with adsorbed or entrapped antigens represent a novel method for controlling the release of immunogens and to optimizing the immune response via selective targeting of the antigen presenting cells [6]. In this exploratory study we evaluated the antiDENV IgG response in mice immunized with bovine serum albumin nanoparticles adsorbed with all four serotypes of inactivated DENV.

\section{Biomed Central}

(c) 2012 Silva et al; licensee BioMed Central Ltd. This is an Open Access article distributed under the terms of the Creative Commons Attribution License (http://creativecommons.org/licenses/by/2.0), which permits unrestricted use, distribution, and reproduction in any medium, provided the original work is properly cited. 


\section{Methods}

\section{Cell culture and virus production}

C6/36 Aedes albopictus cells were grown in L-15 medium (Cultilab, Brazil) supplemented with $10 \%(\mathrm{v} / \mathrm{v})$ heatinactivated fetal bovine serum (FBS) (Cultilab, Brazil), $100 \mu \mathrm{g} / \mathrm{mL}$ penicillin and $100 \mu \mathrm{g} / \mathrm{mL}$ streptomycin at $28^{\circ} \mathrm{C}$. The DENV-1, 2, 3 and 4 were isolated from dengue infected patients in Brazil and were kindly donated by Dr. Erna G. Kroon (Lab Virus, Federal University of Minas Gerais, Brazil). The propagation of each serotype of DENV was carried out in separate C6/36 cell cultures flasks. The cells were infected with DENV-1, 2, 3 or 4 at a multiplicity of infection (MOI) of 0.1 and incubated at $28^{\circ} \mathrm{C}$ for a week. After the development of cell syncytia, the supernatants were harvested, and titrated by standard plaque assay in LLC-MK2 cells [7]. Heat-inactivated virus was prepared by incubating virus samples in a $55^{\circ} \mathrm{C}$ water bath for one hour as described previously [8].

\section{Nanoparticle preparation and characterization}

The nanoparticles were obtained by the addition of ethanol dropwise (ethanol:water relation 1,5:1) to an aqueous solution of bovine serum albumin (BSA) (2\% $\mathrm{w} / \mathrm{v})$. The coacervates were hardened by adding $50 \mu \mathrm{L}$ of $25 \%$ glutaraldehyde while stirring for 2 hours at room temperature. The BSA-nanoparticles were purified by three cycles of centrifugation at 13,000 g for 30 minutes to eliminate free BSA and the excess of the crosslinking agent. The supernatants were removed and the pellets resuspended in sterile PBS (final concentration of 20 $\mathrm{mg} / \mathrm{mL}$ ). For adsorption of inactivated viral particles to the surface of the nanoparticles (NP+DENV), $1 \mathrm{~mL}$ suspension of the tetravalent DENV antigenic suspension (equivalent of $1.2 \times 10^{4}$ plaque forming units (PFU) for each serotype) was incubated with $1 \mathrm{~mL}$ of NP at 20 $\mathrm{mg} / \mathrm{mL}$. After rapid homogenization (30 seconds), the nanoparticles were purified by three successive centrifugations, each at $13,000 \mathrm{~g}$ for 30 minutes, $20^{\circ} \mathrm{C}$. The supernatants were collected after each centrifugation and tested by Bradford assay [9]. To determine the amount of protein adsorbed to the nanoparticles, a colorimetric assay was used and compared to the input protein and that recovered in the supernatants after centrifugation.

The presence of viral particles on the surface of NPs was demonstrated by ELISA assays using the NP+DENV as antigen. Briefly, 96-well microtiter plates were coated with NP+DENV (200 $\mu \mathrm{g} /$ well) in carbonate buffer, incubated overnight at $4{ }^{\circ} \mathrm{C}$ and then washed with PBS containing $0.05 \%$ Tween-20 (PBST). Subsequently, the plates were blocked with $100 \mu \mathrm{l} /$ well of blocking buffer (5\% dry milk in PBST) for $2 \mathrm{~h}$ at $37^{\circ} \mathrm{C}$. After three washes, $100 \mu \mathrm{l}$ of monoclonal anti-DENV-1 (E95), antiDENV-2 (E96), anti-DENV-3 (E51) or DENV-4 (E88) was added at $1 \mu \mathrm{g} / \mathrm{mL}$ [10-12] in triplicate and incubated for $1 \mathrm{~h}$ at $37^{\circ} \mathrm{C}$. After three washes, the plates were incubated for 1 hour at $37^{\circ} \mathrm{C}$ with $100 \mu \mathrm{l} /$ well of horseradish-peroxidase (HRP)-labeled anti-mouse IgG (Sigma) diluted 1:5000 in PBST. After three additional washes, the plates were incubated for 15 minutes with $0.1 \mathrm{ml}$ of $0.045 \% \mathrm{H}_{2} \mathrm{O}_{2}$ and $0.4 \mathrm{mg} / \mathrm{ml}$ of o-phenylenediaminedihydrochloride (OPD) in phosphate-citrate buffer $(0.1 \mathrm{M}$ citric acid, $0.2 \mathrm{M}$ sodium phosphate dibasic, $\mathrm{pH}$ 5.0). The reaction was stopped by adding $50 \mu \mathrm{l}$ of 2 $\mathrm{M} \mathrm{H}_{2} \mathrm{SO}_{4}$. The optical densities were read at $450 \mathrm{~nm}$ with a microplate reader. The zeta potential of the NPs were determined with a Zetasizer 3000 HS (Malvern Instruments, UK). The surface morphology and the diameter of the formulated nanoparticles were visualized by scanning electron microscopy (Model JEOL 560).

\section{Immunization protocol and quantification of anti-DENV and anti-BSA IgG}

Six-week-old male Swiss Webster mice were used for immunizations. All mice were maintained with free access to sterile food and water, and protocols were approved by the local Animal Experimentation Ethics Committee. Mice were immunized via the subcutaneous route using $100 \mu \mathrm{g}$ of NP $(\mathrm{n}=15)$ or NP+DENV $(\mathrm{n}=$ 20 ) on days 0,7 and 14 . The mice were sacrificed 7 days after the last immunization (at day 21). Additional mice were immunized with PBS (negative control) ( $\mathrm{n}=$ 10 ) or $1.2 \times 10^{4} \mathrm{PFU}$ of the tetravalent DENV heat-inactivated antigenic suspension (positive control) $(\mathrm{n}=10)$. Blood was collected by cardiac puncture and sera were separated for ELISA. To perform IgG quantification, 96well microtiter plates were coated with $500 \mathrm{PFU} /$ well of the inactivated DENV particles (serotypes 1 to 4 ) in carbonate buffer or BSA ( $2 \mu \mathrm{g} /$ well). An ELISA was performed exactly as described above for quantitation of viral particles on NP, except virions were captured directly and sera from mice were used as the primary antibody. An analysis of ELISA results was performed using analysis of variance (ANOVA), and the differences between groups were evaluated with Tukey's test.

\section{Plaque Reduction Neutralization assay (PRNA)}

Briefly, heat-inactivated mouse sera were serially diluted two-fold from 1:20 to 1:320 in media and then mixed with a single DENV serotype (20 to $50 \mathrm{PFU} /$ well) and incubated for 1 hour at $37^{\circ} \mathrm{C}$. The mixture was inoculated onto LLC-MK2 cells in 24-well plates. Plates were incubated for $1 \mathrm{~h}$ before media was aspirated and replaced with $0.5 \mathrm{~mL}$ of $0.8 \%$ carboximethylcellulose medium (with $2 \%$ FBS). The plates are incubated at $37^{\circ}$ 
C (5\% CO2) for five days. At that time, cells were stained with a crystal violet solution $(0.5 \%$ crystal violet, $10 \%$ ethanol and $1 \%$ paraformaldehyde) for 20 minutes, washed again, and the viral plaques were counted. The positive-control serum sample was a serum sample derived from a human patient and the antibody titers were 1:40 for DENV-1 and 1:20 for DENV-2, 3 and 4. Experiments were performed in duplicate.

\section{Results and discussion}

The development of a dengue vaccine is considered challenging, because it must provide protective immunity against the four serotypes, without causing adverse side effects associated with incomplete immunity against a single serotype. Although the pathogenesis of the disease and protection mechanisms are not fully understood, the production of neutralizing antibodies is believed to be essential to the effectiveness of a DENV vaccine [13]. Biodegradable nanoparticles made by BSA coated with proteins represent a promising method for in vivo delivery of protein vaccines directly to the immune system.

The resulting BSA nanoparticles had a mean diameter of $686.9 \mathrm{~nm}$ and the mean zeta potential of $35.8 \mathrm{mV}$. Scanning electron micrograph images of the nanoparticles revealed their regular spherical shape (Figure 1A). The BSA nanoparticle adsorbed $28.8 \pm 6.2 \%$ of the total proteins present in the tetravalent DENV antigenic suspension, and the presence of the inactivated viral particles on the surface of the NPs was demonstrated by a conventional ELISA assay using monoclonal antibodies against all four DENV serotypes. As shown (Figure 1B), all four DENV serotypes were detected on the surface of nanoparticles. The adsorption process could be attributed to the force of attraction between virions and BSA. Analogously, hepatitis B virus is able to interact with albumin via its surface proteins, suggesting that the same mechanism could occur between NPs BSA and inactivated DENV viral particles [14].

To investigate if this formulation induced antibody production, groups of outbred Swiss Webster mice were inoculated with $100 \mu \mathrm{g}$ of NP+DNV per mouse, 1, 2 or 3 times, at one week intervals. As a control group, mice were inoculated with an empty NP (naive group) or with $1.2 \times 10^{4} \mathrm{PFU}$ of tetravalent DENV antigenic heat-inactivated suspension (positive control). We observed a robust production of anti-DENV IgG antibodies $(P<0.001)$ in the mice immunized with NP + DENV (Figure 2A). In contrast, the empty NP or NP + DENV failed to induce an anti-BSA antibody response, confirming the relatively poor immunogenicity of BSA. Despite a relatively high level of antiDENV antibodies in the immunized mice (NP+DENV), the PRNT showed an absence $\left(\mathrm{PRNA}_{50}<1 / 20\right)$ of

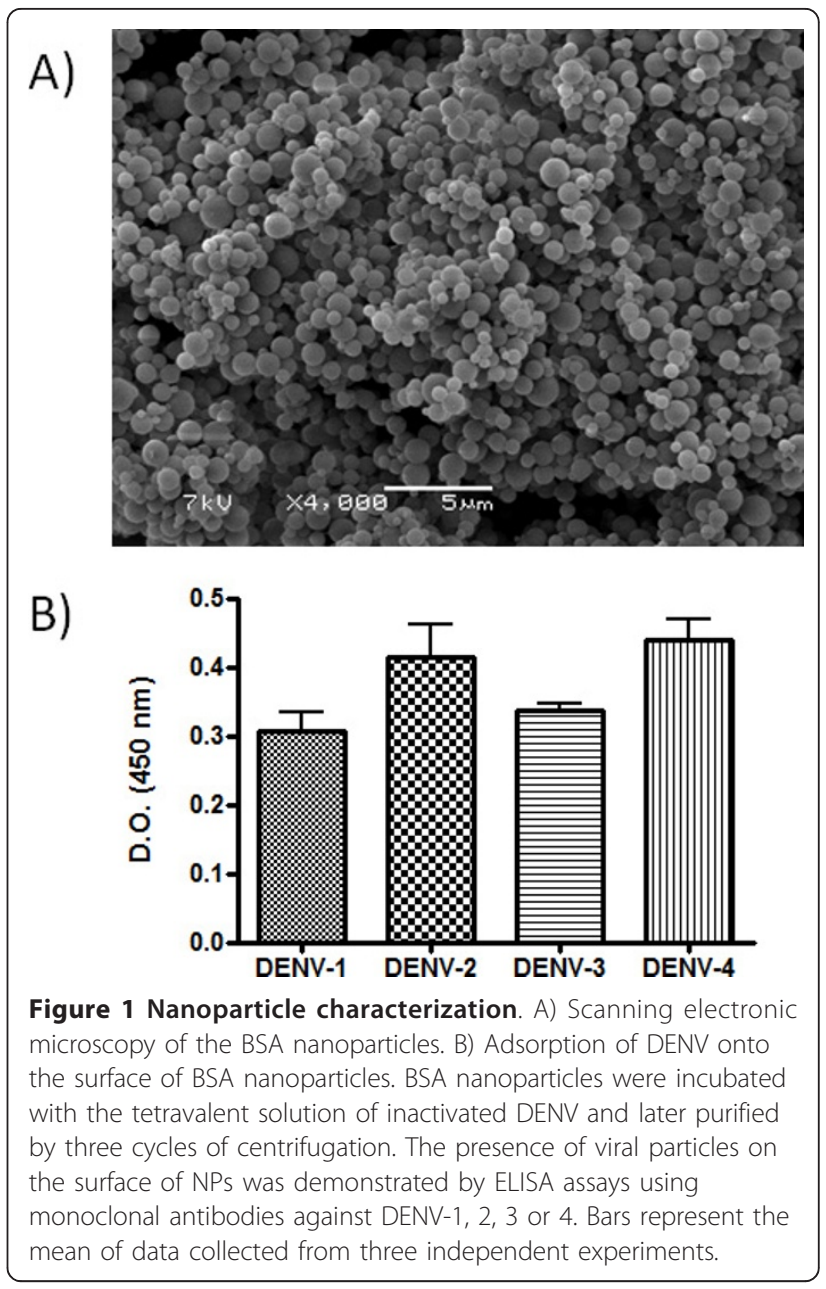

neutralizing activity in the serum of these animals in all dilutions tested (data not showed), although we cannot rule out the possibility of some neutralizing activity in dilutions below 1:20. Recent studies indicate that the antibody response to DENV infection consists of a minor population of strongly neutralizing antibody and a major population of cross-reactive, non-neutralizing antibodies (both prM and E) with potential for enhancement of virus infection and disease [15-17]. However, if a high concentration of all DENV serotypes (above $1.2 \times 10^{4} \mathrm{pfu} / \mathrm{mL}$ ) was used in the adsorption step or a larger concentration of NP + DENV was used in this study, these antibodies could have a neutralizing activity. As nanoparticles are phagocytosed by dendritic cells and other antigen-presenting cells (APCs), the adjuvant effect of BSAnanoparticles could be explained by their rapid internalization by the skin-resident APCs, such as dendritic cells (DC). The interactions of nanoparticles and DCs also could be facilitated by the presence of the envelope protein of DENV that was derived in insect cells, 


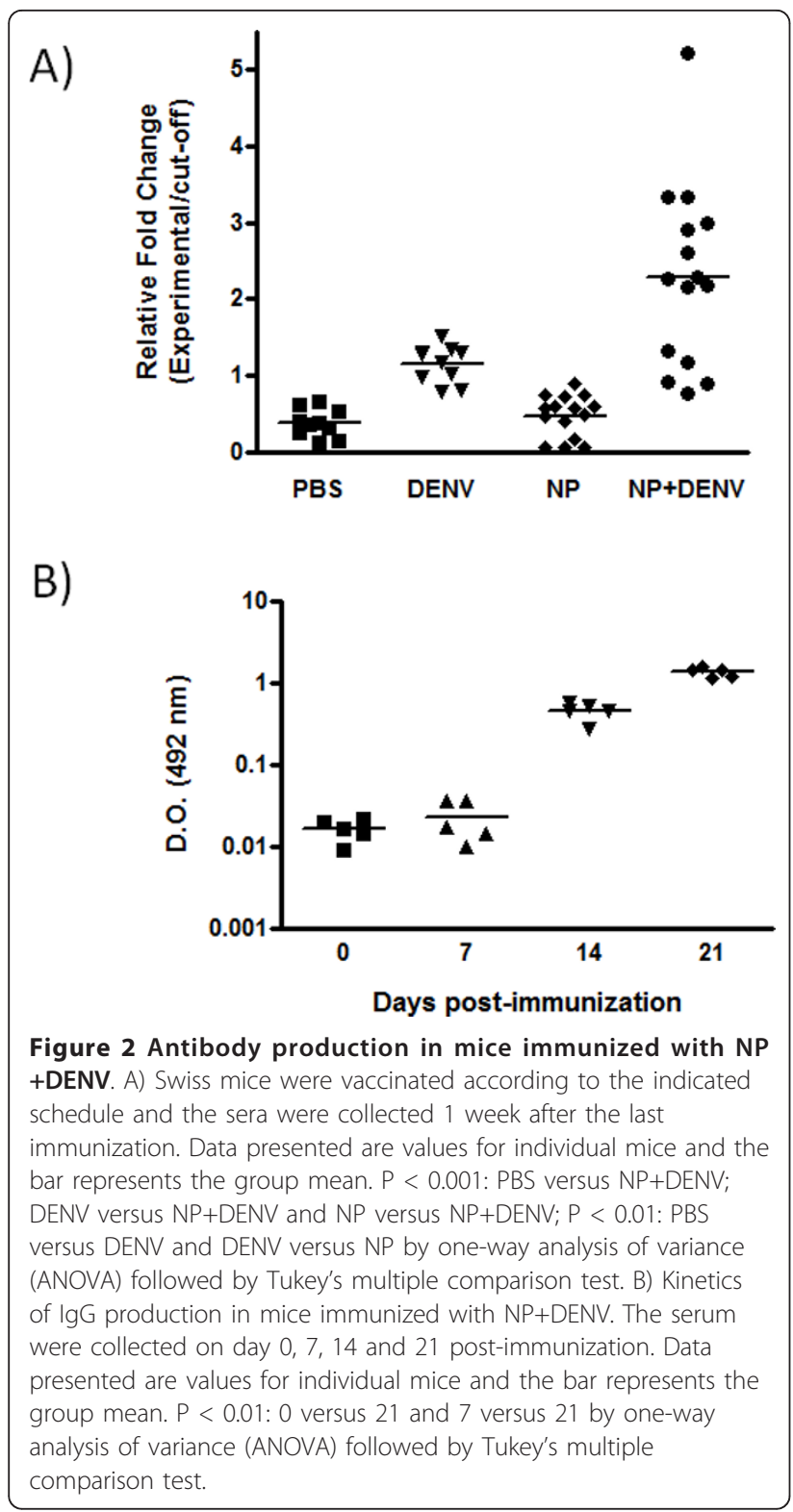

and thus displays high mannose carbohydrates. The DENV E protein is the only glycoprotein exposed on the surface of mature DENV virions and is responsible for attachment to the host cell surface and also plays an important role in viral entry [18]. Studies have shown that this protein binds to the receptors DCSIGN (CD209) and the mannose receptor and facilitates the infection of myeloid cells [18-21]. Another factor that may contribute to the increased production of IgG anti-DENV is innate immune signaling via toll like receptor 7 (TLR7). Inactivated viral particles present on the surface of the NP have single-stranded RNA, which can activate TLR7 to induce the synthesis of pro-inflammatory cytokines [22] that enhances antibody responses. A similar mechanism was described by Geeraedts and colleagues using whole inactivated influenza virus. They demonstrate that the viral RNA present in inactivated virus particles could trigger TLR7 to augment the adaptive humoral responses [23].

\section{Conclusions}

Thus, nanoparticles can induce anti-DENV antibodies readily, although further studies in antigen formulation will be required to induce the production of neutralizing antibodies against all four DENV serotypes.

\section{Acknowledgements}

Financial support was provided by FAPEMIG (APQ-04684-10) and CNPq (565778/2008-0).

\section{Author details}

IInstitute of Biomedical Science, Federal University of Alfenas, Minas Gerais, Brazil. ${ }^{2}$ Department of Chemistry, Federal University of Ouro Preto, Ouro Preto, Minas Gerais, Brazil. ${ }^{3}$ Department of Chemistry, Federal University of Minas Gerais, Belo Horizonte, Minas Gerais, Brazil. ${ }^{4}$ Department of Biological Sciences, Federal University of Ouro Preto, Ouro Preto, Minas Gerais, Brazil. ${ }^{5}$ Laboratory of Medical Entomology, Instituto René Rachou, Fundação Oswaldo Cruz, Belo Horizonte, Minas Gerais, Brazil. ${ }^{6}$ Departments of Medicine, Molecular Microbiology, Pathology \& Immunology, Washington University School of Medicine, Saint Louis, Missouri, USA. 'Virus Laboratory, Department of Microbiology, Institute of Biological Sciences, Federal University of Minas Gerais, Belo Horizonte, MG, Brazil.

\section{Authors' contributions}

EFS, MO, LCCM, BMS and LFLC conceived and designed the method, performed the experiments and interpreted the data. ALA and RZD performed the zeta analysis. HRCA and PFPP perfomed the SEM analysis. MSD developed the monoclonal antibodies used in ELISA assay. ESOR and EGK performed the PRNT. LFLC prepared the manuscript. LFLC, MSD and EFS critically revised the content of the manuscript and gave the final approval of the version to be published. All authors read and approved the final manuscript.

\section{Competing interests}

The authors declare that they have no competing interests.

Received: 27 June 2011 Accepted: 22 March 2012

Published: 22 March 2012

\section{References}

1. Gould EA, Solomon T: Pathogenic flaviviruses. Lancet 2008, 371:500-509.

2. Kyle JL, Harris E: Global spread and persistence of dengue. Annu Rev Microbiol 2008, 62:71-92.

3. Murphy BR, Whitehead SS: Immune response to dengue virus and prospects for a vaccine. Annu Rev Immunol 2011, 29:587-619.

4. Murrell S, Wu SC, Butler M: Review of dengue virus and the development of a vaccine. Biotechnol Adv 2011, 29:239-47.

5. Rice-Ficht AC, Arenas-Gamboa AM, Kahl-McDonagh MM, Ficht TA: Polymeric particles in vaccine delivery. Curr Opin Microbiol 2010, 13:106-112.

6. Klippstein R, Pozo D: Nanotechnology-based manipulation of dendritic cells for enhanced immunotherapy strategies. Nanomedicine 2010, 6:523-529.

7. Ferreira GP, Figueiredo $L B$, Coelho $L F, S P A$ Jr, Cecilio $A B$, Ferreira $P C$, Bonjardim CA, Arantes RM, Campos MA, Kroon EG: Dengue virus 3 clinical isolates show different patterns of virulence in experimental mice infection. Microbes Infect 2010, 12:546-54.

8. Fink J, Gu F, Ling L, Tolfvenstam T, Olfat F, Chin KC, Aw P, George J, Kuznetsov VA, Schreiber M, Vasudevan SG, Hibberd ML: Host gene 
expression profiling of dengue virus infection in cell lines and patients. PLoS Negl Trop Dis 2007, 1:e86.

9. Bradford MM: A rapid and sensitive method for the quantitation of microgram quantities of protein utilizing the principle of protein-dye binding. Anal Biochem 1976, 72:248-54.

10. Brien JD, Austin SK, Sukupolvi-Petty S, O'Brien KM, Johnson S, Fremont DH, Diamond MS: Genotype-specific neutralization and protection by antibodies against dengue virus type 3. J Virol 2010, 84:10630-43.

11. Sukupolvi-Petty S, Austin SK, Engle M, Brien JD, Dowd KA, Williams KL, RicoHesse R, Harris E, Pierson TC, Fremont DH, Diamond MS: Structure and function analysis of therapeutic monoclonal Antibodies against dengue virus type 2. J Virol 2010, 84:9227-39.

12. Shrestha B, Brien JD, Sukupolvi-Petty S, Austin SK, Edeling MA, Kim T, O'Brien KM, Nelson CA, Johnson S, Fremont DH, Diamond MS: The development of therapeutic antibodies that neutralize homologous and heterologous genotypes of dengue virus type 1. PLoS Pathog 2010, 6 : e1000823.

13. Stephenson JR: Understanding dengue pathogenesis: implications for vaccine design. Bull World Health Organ 2005, 83:308-314.

14. Krone B, Lenz A, Heermann KH, Seifer M, Lu XY, Gerlich WH: Interaction between hepatitis $B$ surface proteins and monomeric human serum albumin. Hepatology 1990, 11:1050-1056.

15. de Alwis R, Beltramello M, Messer WB, Sukupolvi-Petty S, Wahala WM, Kraus A, Olivarez NP, Pham Q, Brien JD, Tsai WY, Wang WK, Halstead S, Kliks S, Diamond MS, Baric R, Lanzavecchia A, Sallusto F, de Silva AM: Indepth analysis of the antibody response of individuals exposed to primary dengue virus infection. PLoS Negl Trop Dis 2011, 5:e1188.

16. Schieffelin JS, Costin JM, Nicholson CO, Orgeron NM, Fontaine KA, Isern S, Michael SF, Robinson JE: Neutralizing and non-neutralizing monoclonal antibodies against dengue virus $\mathrm{E}$ protein derived from a naturally infected patient. Virol J 2010, 4:7-28.

17. Beltramello M, Williams KL, Simmons CP, Macagno A, Simonelli L, Quyen NT, Sukupolvi-Petty S, Navarro-Sanchez E, Young PR, de Silva AM, Rey FA, Varani L, Whitehead SS, Diamond MS, Harris E, Lanzavecchia A, Sallusto F: The human immune response to Dengue virus is dominated by highly cross-reactive antibodies endowed with neutralizing and enhancing activity. Cell Host Microbe 2010, 8:271-83.

18. Dejnirattisai $W$, Jumnainsong $A$, Onsirisakul $N$, Fitton $P$, Vasanawathana $S$, Limpitikul W, Puttikhunt C, Edwards C, Duangchinda T, Supasa S, Chawansuntati K, Malasit P, Mongkolsapaya J, Screaton G: Cross-reacting antibodies enhance dengue virus infection in humans. Science 2010, 328:745-8.

19. Mukhopadhyay S, Kuhn RJ, Rossmann MG: A structural perspective of theFlavivirus life cycle. Nat Rev Microbiol 2005, 3:13-22.

20. Miller JL, de Wet BJ, Martinez-Pomares L, Radcliffe CM, Dwek RA, Rudd PM, Gordon S: The mannose receptor mediates dengue virus infection of macrophages. PLoS Pathog 2008, 4:e17.

21. Lozach PY, Burleigh L, Staropoli I, Navarro-Sanchez E, Harriague J, Virelizier UL, Rey FA, Despres P, Arenzana-Seisdedos F, Amara A: Dendritic cell-specific intercellular adhesion molecule 3-grabbing non-integrin (DC-SIGN)-mediated enhancement of dengue virus infection is independent of DC-SIGN internalization signals. J Biol Chem 2005, 280:23698-23708.

22. Wang JP, Liu P, Latz E, Golenbock DT, Finberg RW, Libraty DH: Flavivirus activation of plasmacytoid dendritic cells delineates key elements of TLR7 signaling beyond endosomal recognition. J Immunol 2006, 177:7114-7121

23. Geeraedts F, Goutagny N, Hornung V, Severa M, de Haan A, Pool J, Wilschut J, Fitzgerald KA, Huckriede A: Superior immunogenicity of inactivated whole virus $\mathrm{H} 5 \mathrm{~N} 1$ influenza vaccine is primarily controlled by Toll-like receptor signalling. PLoS Pathog 2008, 29:e1000138.

doi:10.1186/1477-3155-10-13

Cite this article as: Silva et al:: A tetravalent dengue nanoparticle stimulates antibody production in mice. Journal of Nanobiotechnology 2012 10:13.

\section{Submit your next manuscript to BioMed Central and take full advantage of:}

- Convenient online submission

- Thorough peer review

- No space constraints or color figure charges

- Immediate publication on acceptance

- Inclusion in PubMed, CAS, Scopus and Google Scholar

- Research which is freely available for redistribution

Submit your manuscript at www.biomedcentral.com/submit
Biomed Central 